\title{
Analysis of the utilization of supplementary illustrations - an example of the selected teaching units from the fifth grade geography textbook (Republic of Serbia)
}

\author{
Smiljana Đukičin ${ }^{A *}$, Ljubica Ivanović BibićA, Tin LukićA ${ }^{A}$, Zorica Dubovina ${ }^{B}$ \\ Received: July 28, 2014 | Revised: September 30, 2014 | Accepted: November 30, 2014
}

\begin{abstract}
The textbook is one of the elementary teaching aids. It is a very efficient aid utilized to transfer information of the instructional content. Illustrations are a part of the didactic apparatus, contributing to apparentness. Contemporary geography textbooks cannot be imagined without adequate supplementary illustrations. Supplementary illustrations should be clear and unburdened by superfluous details. They should be a sort of an addition to the main text and provide the necessary information of the instructional content.

In order to acquire a better view of the level of usefulness of supplementary illustrations in learning process, a research was carried out in nine schools. The textbook utilized to analyze supplementary illustrations was the textbook for the fifth grade of primary school. Students were asked about the usefulness of supplementary illustrations in learning new material and in independent learning. Additionally, questions were related to the usefulness of supplementary illustrations in reiterating material as well.
\end{abstract}

Statistical data processing produced results that corroborated the tremendous significance of correctly and properly selected supplementary illustrations in geography textbooks.

Key words: geography teaching, textbook, illustration, principle of apparentness, didactic apparatus, physical geography

\section{Introduction}

The organisation of educational work is complex, and its study is somewhat complicated (Leščešen, et al., 2013). Geographical education has been seen as a basic tool to contribute to the change of conceptions, values and attitudes (Tracana, et al., 2008). Many experts insisted on the importance that geographical knowledge had for governors, farmers, retailers and military men. It also took into account the role it played in the education of citizens. For this reason, geography teaching had important place in the curriculum worldwide
(Meneses, Calderón, 2007). Geography teaching fulfils both, a general and a more specific role in social reproduction (Morgan, 2003). The geography textbook is an inviolable learning/working tool for students. It is an irreplaceable teaching aid regardless of the development of teaching technology and any attempts to follow the teaching process in coordination with the development of that technology.

The textbook is a key constituent of the so-called "lower" educational technology, since its most significant material basis is constituted of the classical ex-

\footnotetext{
A University of Novi Sad, Faculty of Sciences, Department of Geography, Tourism and Hotel Management, Trg Dositeja Obradovića 3, 21000 Novi Sad, Serbia; smiljanadjukicin@gmail.com

B Laza Kostić Gymnasium, Laze Lazarevića 1, 21000 Novi Sad, Serbia

* Corresponding author: Smiljana Đukičin, e-mail: smiljanadjukicin@gmail.com
} 
pressive form - the text. However, as a markedly dedicated teaching aid, the textbook has an accompanying functional and scientific component within its content in the form of the didactic-methodical apparatus, as well (Romelić, 2003).

The textbook is viewed as a quite efficient tool to establish coordination, i.e. to provide precise and focused instructions with an optimal utilization of the required instructional content (Rudić, 1991). The expression textbook pattern is also not (yet) clearly defined in the didactic theory of the textbook (Senegačnik, 2010).

The illustration is a very efficient and pedagogically favourable tool, since it is based on one of the basic didactic principles, i.e. the principle of apparentness (Ivkov, et al., 2010). Contemporary geography textbooks cannot be imagined without adequate supplementary illustrations which accompany the instructional content. These supplementary illustrations stands as an excellent addition to the main text respectively. In order for the illustration to be comprehensible, it is necessary to focus on its content/structure, as well as on the visual elements (Ivanović, 2005).

In order to acquire a more objective view of the utilization of supplementary illustrations in the fifth grade geography textbook, a survey was carried out in nine schools in Vojvodina (Northern Serbia), with 443 students as respondents. During the constuction of the questionnaire, the fifth grade geography textbook written by Rada Sitarica and Milutin Tadić, published by the Institute for Textbooks and Teaching Aids (orig. "Zavod za udžbenike i nastavna sredstva") in 2012, was used. The survey was carried out in the period from March to May 2014.

\section{Theoretical overview of the utilization of supplementary illustrations}

There are numerous definitions for the publication we call the "textbook", i.e. the main teaching aid. The conclusion that could be made based on those definitions is that the material of a given course in them should be adapted to the age of the persons at whom the textbook is aimed, and the material should be presented clearly, systematically and synoptically. Unfortunately, in recent times that has not been the case (e.g. Dragović, 2012). Textbooks are treated as mirrors of course syllabi, produced by both those who write/edit such books and those who use them (Johnston, 2006).

Dikić (1997) claims the following in relation to the presence of visual elements in the teaching process: "The picture, as well as other illustrational aids, is a significant teaching aid which concretizes the details of the teaching process and expands the boundaries and the dimensions of its apparentness. A well-select- ed and properly utilized picture invigorates the pace of teaching and has a positive impact on the dynamics of the teaching process." Moreover, the above-mentioned author points out that textbook illustrations/ pictures impact the learning process in several ways as well. Apart from having an impact on the development of observing abilities and concentration, it develops interest and thus supports motivation during learning. However, the main objective of any illustrated presentation in a textbook is to contribute to the illumination of the topic of learning. "Observing is a fundamental part of the learning process and it greatly impacts its effectiveness" (Dikić, 1997: 86).

In their work "The Guide to a Good Textbook ", Ivić et al., (2008) pointed out that it is extremely important to separate thematic units and their parts spatially and visually-graphically in a textbook, as well as to have adequate supplementary illustrations in addition to the teaching units. Supplementary illustrations should be clear and not overloaded with superfluous visual elements. Presence of a large amount of detail in illustrations makes them unclear and without their primary purpose.

Supplementary illustrations should not produce disinterest within the students and divert their attention to the topics unrelated to the lesson. They must leave impression on the students, have didactic value and be clear. The colour and visual dimension of a picture in geography teaching facilitates the students to spot what is relevant and what is irrelevant in the illustration and to establish a vivid idea of a geographic phenomenon and/or its structure (Romelić, 2005).

\section{Methods and data}

The data utilized in the empiric segment of the research was acquired in the field, through a research performed in primary schools. The survey was carried out in the period from March to May 2014. A closed type of questionnaire was used, as an appropriate and methodologically adequate method to acquire representative data. The questionnaire contained questions related to the geography textbook for the fifth grade of primary school written by Rada Sitarica and Milutin Tadić (2012), published by the Institute for Textbooks and Teaching Aids. The questionnaire had seven questions relevant to the topic of the research. Research quality was enhanced by the fact that the survey was carried out on the basis of the principles of anonymity, voluntariness and impartiality. The data acquired through the research was statistically processed using the SPSS Statistics software.

During the research, and based on the current situation in the field, it was observed that a large number of primary schools on the territory of Novi Sad 
Municipality and the surrounding area do not use the textbook by the Institute for Textbooks and Teaching Aids publishing house. The aforementioned textbook is used merely in $29.4 \%$ of primary schools, while $58.8 \%$ of schools use the textbook by the Klett publishing house, and $11.8 \%$ did not want to participate in this survey.

In order to increase the quality of the analysis, surveys were additionally carried out in two schools outside of the Municipality of Novi Sad - a primary school in the Municipality of Žabalj and a primary school in the Municipality of Žitište.

The research included 443 primary school students. The survey was carried out in the following primary schools:

- Aleksa Šantić Primary School - Stepanovićevo (51 respondents),

- Veljko Vlahović Primary School - Šangaj (18 respondents),

- Veljko Petrović Primary School - Begeč (16 respondents),

- Vuk Karadžić Primary School - Novi Sad (25 respondents),

- Đura Daničić Primary School - Novi Sad (56 respondents),

- Jovan Popović Primary School - Novi Sad (69 respondents),

- Petefi Šandor Primary School - Novi Sad (96 respondents),

- Miloš Crnjanski Primary School - Žabalj (106 respondents),

- Petar Kočić Primary School - Čestereg (6 respondents).

\section{Results}

Based on the statistical analysis of the material acquired in the field, results pointed out the fact that supplementary illustrations are utilized to a great extent both in learning at school and in learning at home.

The first question in the questionnaire was related to the use of pictures (appendices) from the geography textbook when processing new material. Most respondents $(33.2 \%)$ stated that they frequently utilize appendices when learning new material and $27.3 \%$ of the respondents stated that they use appendices occasionally. As much as $26.0 \%$ of the respondents stated that they use textbook appendices every time when learning new material. Figure 1 illustrates the aforementioned results.

Analysis of the responses shows that geography teachers generally direct their students to use textbook appendices when dealing with new subject material in order to better explain the presented informa- tion, and through the application of various teaching methods and types. This fact greatly stresses the significance of proper selection and presentation of certain supplementary illustrations to facilitate more effective adoption of knowledge. Pictures in textbooks not only concretise and strengthen issues covered in class and mentioned in the book, but also provide additional motives for students (Yasar, Seremet, 2007).

The second question in the questionnaire was related to the use of supplementary illustrations from the textbook in independent activities by the students, i.e. learning at home. The responses to this question were rather uniform. $27.8 \%$ of the total number of students stated that they frequently utilize textbook appendices when working independently, and as much as $27.1 \%$ of the students stated that they utilize the appendices occasionally, while $25.5 \%$ stated that they use the appendices every time. Only $4.1 \%$ of the students stated that they never use textbook appendices when studying at home (Figure 2).

This level of frequency of utilization of supplementary illustrations in studying at home is very encouraging, since teachers are compelled to direct their students to utilize illustrational tools as frequently as possible in order to facilitate more effective individual learning.

Geography textbooks convey images of the world that usually remain anchored in the student's mental map for many years (Hamann, 2007).

The third question in the survey aimed to verify the general function of illustrational appendices as a key

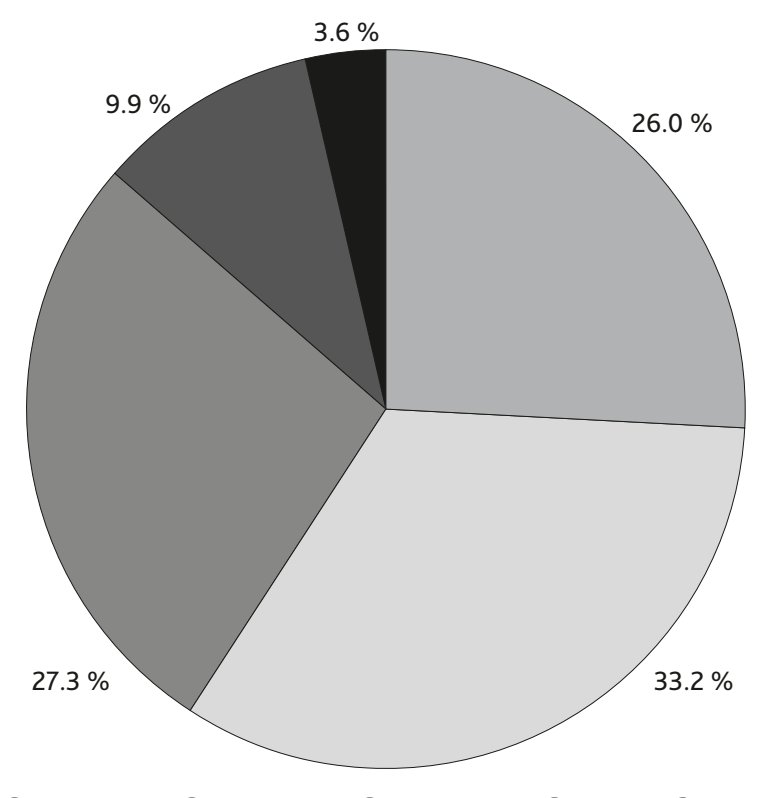

Every time $\bigcirc$ frequently $\bigcirc$ sometimes $\bigcirc$ Rarely Never

Figure 1. Utilization frequency of images (appendices) from analysed textbook in processing new subject material

Source: Authors research. 


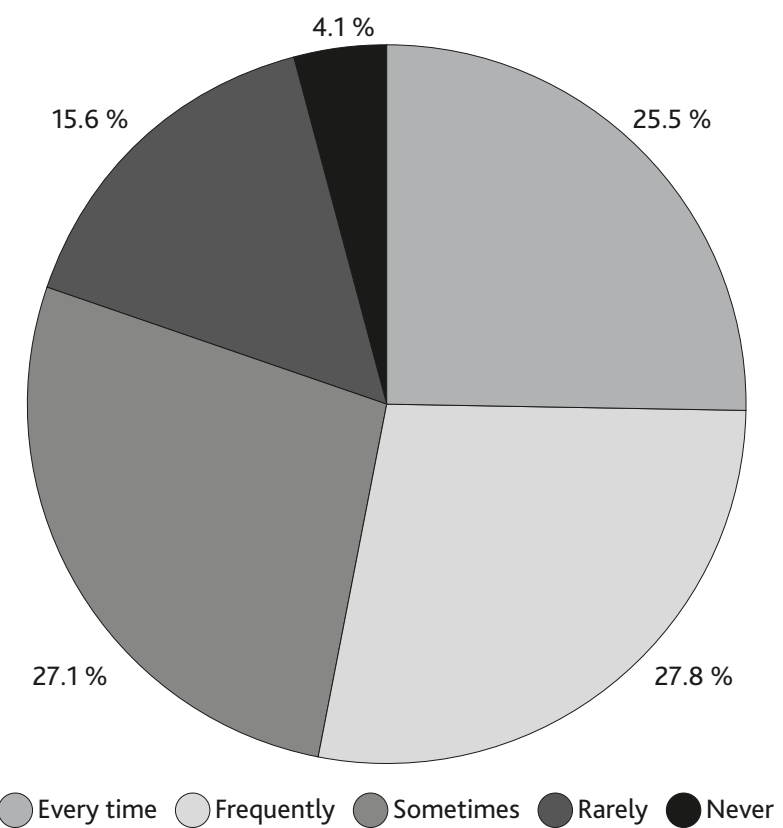

Figure 2. Utilization frequency of supplementary illustrations from analysed textbook in studying at home Source: Authors research.

element of the didactic apparatus. Based on the analyzed results, it has been observed that $50.8 \%$ of the respondents claim that appendices are sometimes beneficial to their understanding of the subject material, $46.0 \%$ claim that the use of appendices always helps them to understand the subject material, and only $3.2 \%$ state that appendices never facilitate their better understanding of the subject material (Figure 3).

The fourth question in the survey was related to the analysis of supplementary illustrations from the teaching unit "Earth's internal structure and relief - rocks and fossils", with the aim to indicate the inadequate presence of supplementary illustrational materials which are significantly divergent from their basic function - clarifying the presented textual information. In this question, the students had to open the textbook at the aforementioned teaching unit and look at the illustrational appendices on page 70. Afterwards, they were asked whether they recalled the topic explained in the teaching unit based on the illustration.

Most of the students, i.e. 33.2\%, stated that they could recall what had been explained in the given lesson based on the observed appendices. As much as $27.5 \%$ of the students stated that they did not recall anything from the lesson when using appendices, while $20.8 \%$ stated that they recalled certain things from the lesson, and only $18.5 \%$ stated that the appendices helped them to fully recall the material presented in the lesson (Figure 4).

The following question is in a causal relationship with question number 4 while, in a certain way, concretizing the qualitative use of supplementary illustra-

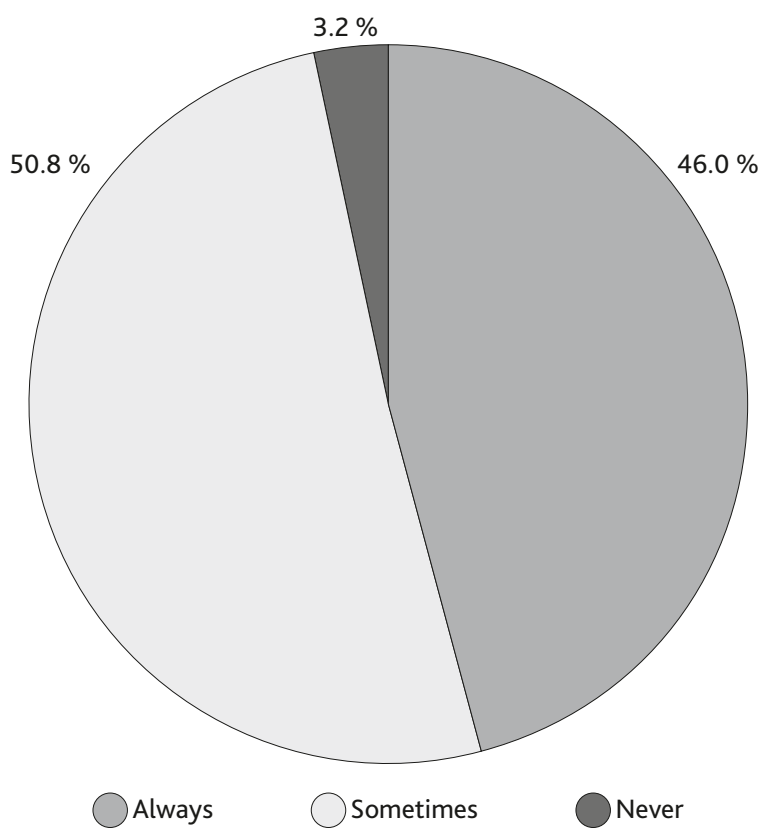

Figure 3. Use of appendices in the process of learning Source: Authors research.

tion in learning new material. The respondents were asked to read the questions at the end of the teaching unit, without reading the lesson. Supplementary illustrations were supposed to serve them as a reminder during independent examination of the given teaching unit. However, the analysis proved the opposite, as illustrated by the graph below (Figure 5). The fifth question in the survey was as follows: "Read all the questions at the end of the lesson, do not read the lesson! Can you provide answers to the questions by using only the illustrations (appendices) from the lesson as a reminder?"

Most of the respondents, $58.0 \%$, stated that, if they used the lesson appendices as a reminder, they could only answer certain questions, while $26.6 \%$ stated that they could not answer the given questions in this way, and only $15.3 \%$ stated that they knew the answers to all questions (Figure 5).

These results obviously point to a lacking presence of illustrational tools in the teaching unit. When processing such abstract instructional content, it is not recommended to provide an "final product" as a supplementary illustration, as fully shown in the Figure 6 (1). A much more appropriate illustration, which would be completely in line with the main text, should be a process diagram of the "rock cycle" as provided in Figure 6 (2). In this way, the students would more easily grasp the process of creation of the three main groups of rocks that are the constituents of the Earth's crust.

Question number six was intended to illustrate the extent to which well-designed and represented supplementary illustrations can contribute to the better 


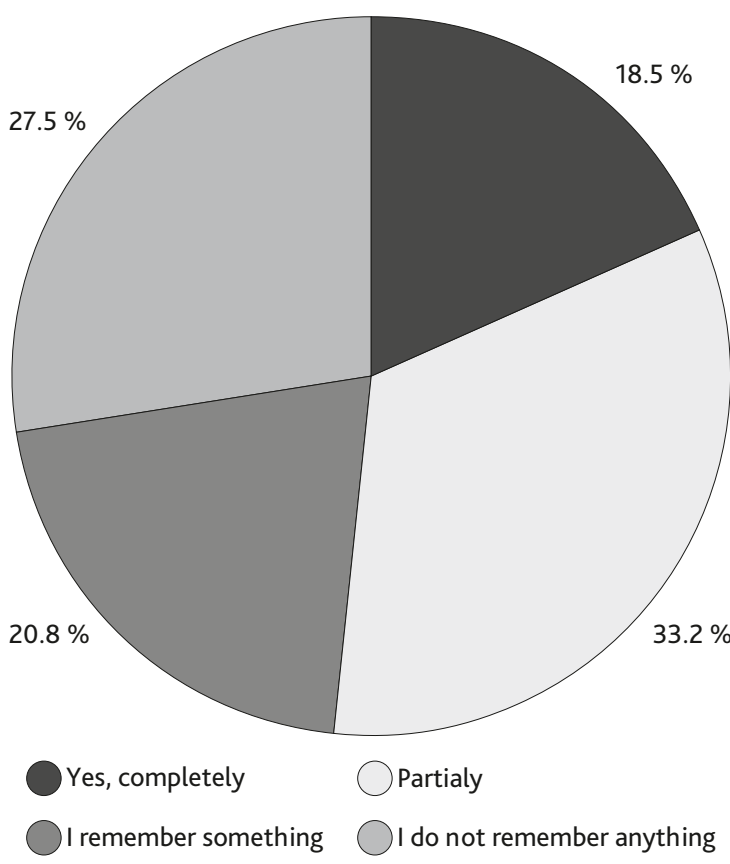

Figure 4. Analysis of the provided supplementary illustrations aimed towards greater understanding of the teaching unit "Earth's internal structure and relief - rocks and fossils"

Source: Authors research.

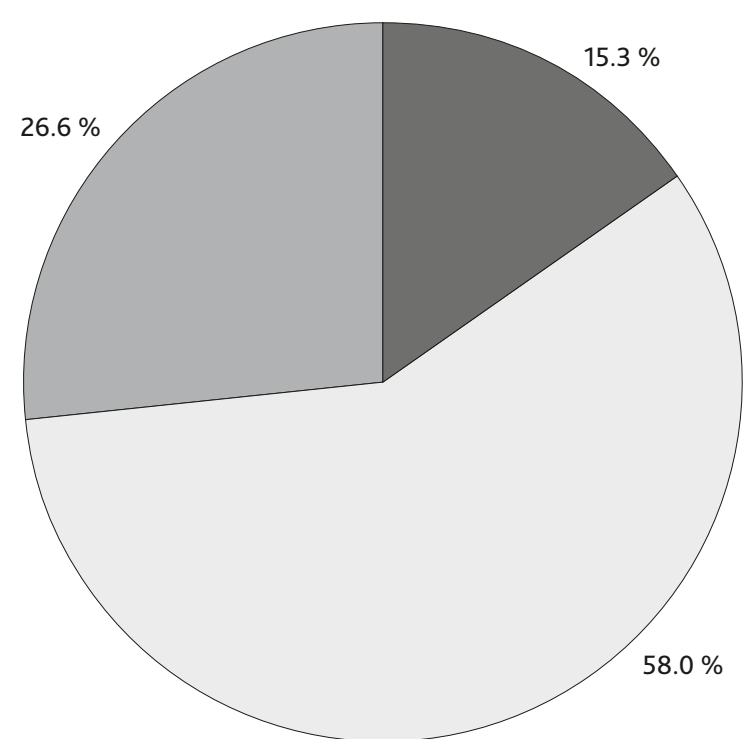

I know all the answers 1 know the answers to some questions I do not know the answers to questions

Figure 5. Ability to provide answers to the control questions with the aid of appendices to the lesson "Earth's internal structure and relief - rocks and fossils" Source: Authors research.

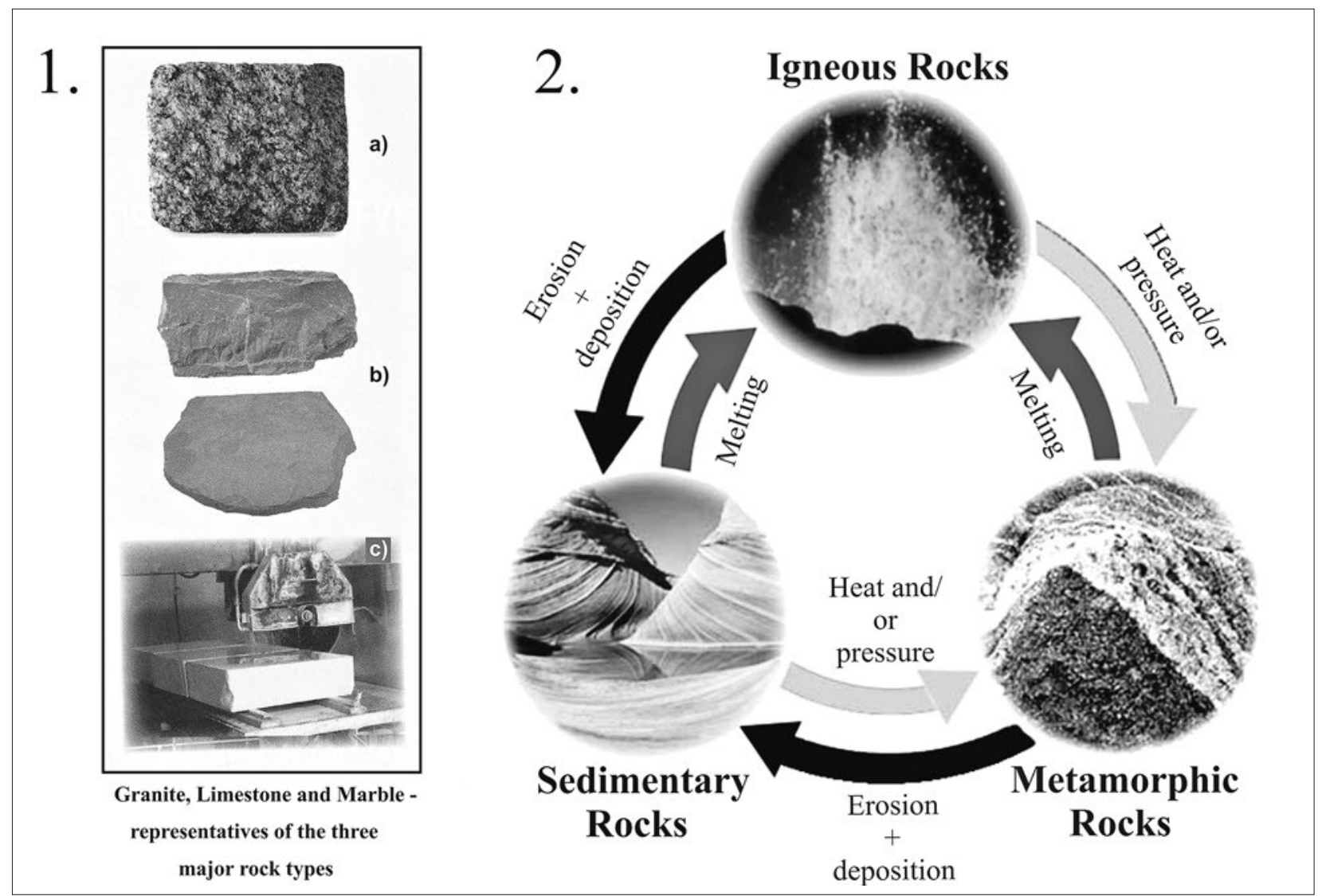

Figure 6. Comparison of an inadequate supplementary illustration (1) and a more adequate proposed illustrational solution (2)

(Source: modified after Sitarica, Tadić, 2012; Lukić et al. 2010) 


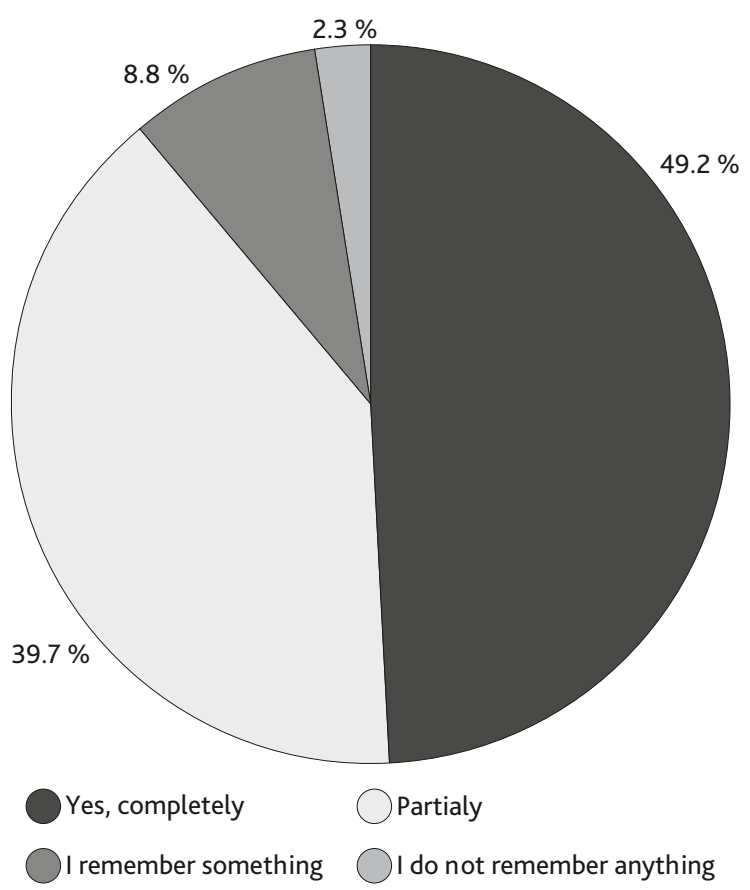

Figure 7. Analysis of the represented supplementary illustrations aimed towards better understanding of the teaching unit "The creation and inner structure of the Earth"

Source: Authors research

adoption of the subject material. Nearly half of the respondents, or $49.2 \%$, stated that they could fully recall what had been explained in the teaching unit "The creation and inner structure of the Earth" based on the images. A large number of students, or $39.7 \%$, also stated that they could only partially recall what had been explained in the given lesson based on the appendices to the lesson. Only $8.8 \%$ of the respondents stated that they recalled certain things, and just 2.3\% of the students claimed they did not recall anything (Figure 7).

The acquired results show that well designed illustrational appendices greatly facilitate the learning of new and rather abstract elements of physical geography.

The last question in the survey was related to the ability to provide answers to the control questions from the teaching unit if images (illustrational appendices) are used as a reminder. The selected teaching unit was: "The creation and inner structure of the Earth". The students provided positive answers for the most part, with $56.2 \%$ who stated that they knew the answers only to certain questions, while $41.8 \%$ claimed that they knew the answers to all questions. Only 2.0\% of the students stated that they did not know the answers to the given questions. The results are illustrated by the Figure 8 .

These results can be explained by the presence of certain control questions that provided the answers

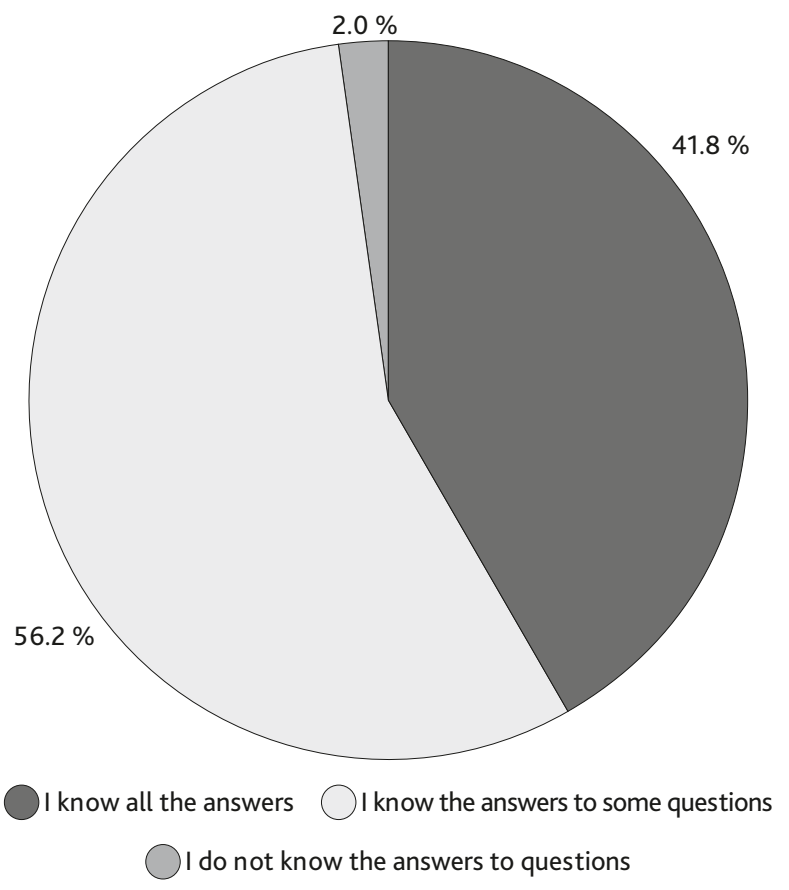

Figure 8. Ability to answer control questions with the aid of the appendices to the lesson "The creation and inner structure of the Earth"

Source: Authors research.

which cannot be acquired based on the provided textbook illustrations. Moreover, certain complexity and abstractness of the instructional content of geography lessons for the fifth grade, as well as a relative deficit in terms of the number of classes annually, are large contributing factors to the more laborious adoption of the foreseen material by the students.

\section{Conclusion}

Among the teaching aids which have strong effect on student development and which are significant mediators in the communication between the students, the teacher and the instructional content, the textbook plays the most important role. This fact is reflected in its bi-functionality in terms of simultaneously functioning as the source and the transmitter of knowledge.

Illustrational tools, as symbolic systems and companions to the main text, are a major segment of the didactic apparatus. Supplementary illustrations have particular didactic significance, as they serve to complement the main text, while more closely illustrating its basic information.

Analysis of the acquired results showed that the ideal textbook for the needs of geography teaching in Serbia is non-existent. However, the correct selection of illustrational appendices and qualitative presence of the didactic apparatus in general, greatly contrib- 
ute to a more efficient adoption of abstract concepts and materials related to physical geography. The survey research showed that supplementary illustrations in a textbook play an important role, both during learning at school and during independent learning. Nonetheless, not all illustrations are equally good and apparent, nor do they provide the students with associations to the real content of the teaching units. Certain illustrations are confusing and they do not provide sufficient aid in the process of reiterating the material from the analyzed textbook.

The shortcomings and oversights in geography textbooks, as well as the process of alleviating certain shortcomings, should be approached in a more critical and an objective manner in order to create a higher quality textbook in line with the requirements of the contemporary teaching process.

\section{References}

Dikić, S. 1997. Typhlology. First Edition, Faculty of Special Education and Rehabilitation, University of Belgrade. (in Serbian)

Dragović, M. K. 2012. On the Excess of Visual Elements in Many Contemporary Textbooks - With a Special Emphasis on Foreign Language Textbooks. Pedagogical Reality 58 (3), 447-455. (in Serbian with English summary)

Hamann, B. 2007. Australia in German Geography Textbooks for Middle Schools. International Research in Geographical \& Environmental Education $16(2), 135-146$.

Ivanović, Lj. 2005. Application of the Illustrational-Demonstrative Method on Instructional Content in Fifth Grade Geography Teaching. University of Novi Sad, Faculty of Sciences, Department of Geography, Tourism and Hotel Management. (in Serbian)

Ivić, I., Antić, S., Pešikan, A. 2008. Guide to a Good Textbook: General Quality Standards for Textbooks. Platoneum, Novi Sad. (in Serbian)

Ivkov, A., Đukičin, S., Milanković, J. 2010. Analysis of the Use of Images as a Geography Teaching Aid. Pedagogical Reality 56 (5-6), 421-432. (in Serbian with English summary)

Leščešen, I., Ivanović Bibić, Lj., Dragin, A., Balent, D. 2013. Problems of teaching organisation in com- bined (Split) classes in rural areas of the Republic of Serbia. Geographica Pannonica 17 (2), 54-59.

Lukić, T., Ivanović, Lj., Seferović, S., Dolinaj, D., Ivkov-Džigurski, A. 2010. Some problem aspects of the use of additional textbook illustrations: case study of selected parts in geography textbook for fifth grade of elementary school. $2^{\text {nd }}$ Serbian Geographer's Congress-Towards Europe, Novi Sad, December $10^{\text {th }}-11^{\text {th }}$ 2010, Abstract book, 141.

Meneses, L. A., Calderón, J. C. 2007. Social Representations of National Territory and Citizenship in Nineteenth-century History and Geography Textbooks of the Colombian Caribbean Region. Paedagogica Historica 43 (5), 701-713.

Morgan, J. 2003. Imagined Country: National Environmental Ideologies in School Geography Textbooks. Antipode 35 (3), 444.

Rohnston, J. 2006. The politics of changing human geography's agenda: textbooks and the representation of increasing diversity. Transactions of the Institute of British Geographers 31 (3), 286-303.

Romelić, J. 2003. Methodology of Geography Teaching. Faculty of Sciences, Department of Geography, Tourism and Hotel Management, Novi Sad. (in Serbian)

Romelić, J. 2005. Methods in Geography Teaching with an Impact on Student Activation. Globus 30, 21-39. (in Serbian)

Senegačnik, J. (2010). The extent and content of the presentation of the geography of Europe in school textbooks in European countries. Acta geographica Slovenica 50 (1), 85-113.

Rudić, V. 1991. Methodology of Geography Teaching. Naučna knjiga, Belgrade. (in Serbian)

Tadić, M., Sitarica. R. 2012. Geography for 5th grade. Institute for Textbooks, Belgrade. (in Serbian)

Tracana, R. B., Carvalho, G., Ferreira, C., Ferreira, M. E. 2008. Analysing the Theme of Pollution in Portuguese Geography and Biology Textbooks. International Research in Geographical \& Environmental Education 17 (3), 199-211.

Yasar, O., Seremet, M. 2007. A Comparative Analysis Regarding Pictures Included in Secondary School Geography Textbooks Taught in Turkey. International Research in Geographical \& Environmental Education 16 (2), 157-187. 